This PDF is a selection from an out-of-print volume from the National Bureau of Economic Research

Volume Title: NBER Macroeconomics Annual 1991, Volume 6

Volume Author/Editor: Olivier Jean Blanchard and Stanley Fischer, editors

Volume Publisher: MIT Press

Volume ISBN: 0-262-02335-0

Volume URL: http://www.nber.org/books/blan91-1

Conference Date: March 8-9, 1991

Publication Date: January 1991

Chapter Title: Privatization in Eastern Europe: Incentives and the Economi of Transition

Chapter Author: Jean Tirole

Chapter URL: http://www.nber.org/chapters/c10984

Chapter pages in book: (p. 221 - 268) 
Jean Tirole

MIT

\section{Privatization in Eastern Europe: Incentives and the Economics of Transition*}

\section{Introduction}

The transfer of most state industrial property into private ownership is likely to be the most difficult element of the large-scale institutional and policy reform in Eastern Europe (EE). Although there have been recent privatization programs in several other countries, ${ }^{1}$ most lessons of these experiments cannot be directly transposed to the specific EE environment. Economists must thus start from first principles to find techniques of privatization that will perform decently in this environment. The goal of this paper is to discuss how incentives and market structure considerations ought to guide the choice of sequencing and institutions.

\subsection{ASSUMPTIONS}

To circumscribe the task, we make the following assumptions:

First we take it for granted that the long-run target is some form of capitalist economy. There are several variants on this long-term goal, with respect to the role of debt and equity, the involvement of banks and

* This paper was prepared for the NBER Macroeconomics Meetings, March 8 and 9, 1991. It has benefited from the access to several recent discussions of privatization (see references), in particular Blanchard et al. (1990) and Hinds (1990). Accordingly, the notes skip over several issues discussed in much detail in the literature, and build on previous work by emphasizing incentives and market structure issues.

The author is grateful to the discussants and to Philippe Aghion, Olivier Blanchard, Mathias Dewatripont, Stan Fischer, and especially Paul Joskow for helpful discussions, and to the Institute for Policy Reform and the National Science Foundation for financial support.

1. E.g. in western Europe (in particular in the United Kingdom) and in Chile. Assessments of these experiments can be found in Vickers and Yarrow $(1988,1990 \mathrm{a})$ and in a World Bank report (1988). 
workers in the control of the firms, or the size of the safety net. ${ }^{2}$ While the final destination is important over the long run, its choice belongs to the realm of fine tuning when one confronts the immense difficulties for the short and medium run. Unless the transition path has permanent consequences on the governance structures (perhaps for political economy reasons), the overwhelming question facing EE is less the exact target than whether this target will be reached in reasonable time and at a bearable cost.

Second, we assume that governments will be able to start the privatization process by renationalizing industries, i.e., that the government will succeed in reclaiming ownership and redistribute it. It is a common mistake to presume that $\mathrm{EE}$ economies emerge from central planning. ${ }^{3}$ Most countries have granted substantial independence to firms and governments will need to regain control over them [Czechoslovakia and (former) East Germany have recentralized control, but Hungary, Poland, and Yugoslavia have not yet done so]. The initial perception of the ownership structure has been somewhat confused with employees running firms and pushing their claims to ownership. This situation has several unfortunate aspects. A serious short-run issue is that some managers, mostly members of the nomenklatura, have engaged in "spontaneous privatization" and stripped some assets of their firms through transfer pricing, sweet deals with foreigners, and other plundering devices. Governments, e.g., in Poland, have tried to halt such practices. The long-term concern is that autonomy has raised employees' expectations over their receiving ownership of their firms. However, distributing shares solely to the firms' employees would create inequities between manufacturing and nonmanufacturing sector employees, and across employees of the manufacturing sector (because of the substantial differences in the productivity of capital). Furthermore, employee ownership may well reduce investment and lead to decapitalization. ${ }^{4,5}$ While regain-

2. In particular western economies exhibit a wide variety of governance structures. For instance, the German codetermination system involves employees in the control process more than American institutions. The equity market is more developed in the United States than in Germany or in Japan. Banks by and large do not own equity in the United States (which have witnessed a substantial decline of banker control of large corporations in the twentieth century, encouraged in particular by legislations such as the Glass Steagall Act requiring the separation of commercial and investment banking). In contrast, banks play a substantial role in controlling German and Japanese firms (see Narayanan, 1991, for a recent assessment).

3. See Hinds (1990) for a good discussion.

4. See Bradley and Gelb (1982,1985), Grosfeld (1990), and Lipton and Sachs (1990) for discussions of employee stock ownership.

5. In principle, inefficient employee control over the firm may be avoided even if the government needs the employees' agreement to renationalize. It would suffice to compensate employees for the expected present discounted value of the stream of benefits 
ing control over the firms may prove difficult in some countries, this paper assumes that this will happen, and we will not investigate incentives if renationalization turns out to be politically infeasible.

Third, we assume for the purpose of the discussion that the ownership claims will be distributed freely to the population rather than sold. While this assumption is not crucial, one can make a case that it is not unreasonable. Selling the shares in a nondiscriminatory way would create transactional nightmares (with millions of individuals buying thousands of firms). It would require inexperienced and uninformed citizens to invest substantial amounts of time to assess the values of firms (or holdings of firms). Last, it would create substantial inequities, first, by favoring informed and educated citizens, and, second, by laundering the cash savings of the members of the nomenklatura and the entrepreneurs who got rich during the communist regime and during the uncertain period following its fall. For these reasons, giveaways have been recommended in most proposals. ${ }^{6}$

\subsection{THE OBJECTIVES OF PRIVATIZATION}

We take it that capitalism is not wanted for the sake of capitalism. Capitalism is at best viewed as an instrument to achieve efficiency. It is important to identify its crucial features and to wonder whether these are likely to prevail in the short- and medium-term EE environment. That is, will the incentives of the firms' insiders (in particular, management) and outsiders (shareholders, creditors, regulators) function well in this environment? While efficiency will be the main concern of this paper, fairness is quite critical as well. A major benefit of the current situation in EE is the initial equality of ownership of physical assets. ${ }^{7}$ Surely, the policies to be put in

they would obtain under employee ownership. However, such a lump-sum payment would prove prohibitively expensive for the current government. Because the current administration cannot credibly commit to future lump-sum transfers, one way of buying employees out of control is to grant them a minority stake (e.g., 20\%) in their firms. What they lose in terms of share of profits, they may somewhat regain through higher profits generated by higher investment.

6. See Borensztein and Kumar (1990) for a useful survey of some recent proposals and Fischer (1991) for a good discussion of the sale vs. distribution issue. The discussion above suggests giving shares of the firms or of holding companies to all citizens. We will later discuss the option of allocating firms to a small number of individuals. Other methods that have been suggested include the free distribution of some shares and the sale of some other shares, as well as holding back some shares for later sales when uncertainty has been reduced.

7. In principle, the assets belong to the State, that is, to all citizens; see, however, the previous discussion on perceived claims to ownership. There are of course also inequalities in human capital and in monetary holdings. We will not discuss the reabsorption of monetary holdings (the so-called overhang, accumulated mainly by the nomenklatura) in the context of privatization, as we favor confiscation through macroeconomic techniques. 
place to supply the appropriate incentives will create substantial income inequalities, of the order of those in western economies, say. But we would find it disappointing if the privatization process created wealth inequalities beyond those that will naturally emerge over time from income, and thus savings inequalities. Besides this normative statement, positive reasons call for a "broad-based" privatization policy. Excessive inequalities combined with general economic difficulties and unrealistic expectations concerning the growth of income are likely either to fail to attract enough political support or to create distrust in the new economic institutions and might have grave consequences in economically and politically unstable countries.

Most privatization proposals pay only lip service to our third objective, the creation of an appropriate market structure. EE firms are highly horizontally and vertically integrated. As a rough approximation most industries are served by a national monopoly. And previous input assurance concerns have led most firms to produce their own capital goods and other inputs, such as maintenance, repairs, and transportation. Free markets therefore raise the two concerns of horizontal collusion and of vertical foreclosure of suppliers' and buyers' markets. Substantial restructuring will be needed to create market structures that resemble those of western economies (where anticompetitive concerns are serious, but pure monopolies are rare and firms are much less vertically integrated). This form of competition-oriented restructuring (to contrast it with efficiencyoriented restructuring, which is meant to improve firm management and discover synergies across units) will not be voluntarily undertaken by the private sector as it reduces profits. Most proposals dismiss the issue by invoking, first, trade liberalization and the emergence of foreign competition, and, second, antitrust legislation. While both policies will be useful ingredients of a competition policy, by themselves they are unlikely to be sufficient to create appropriate market structures for reasons discussed in Section 5. The creation of competitive markets is thus not an independent appendix to the privatization program.

\subsection{SCOPE OF THE ANALYSIS}

We will follow other papers on privatization by focusing on the major industrial enterprises (for instance, in Poland, the 500 enterprises accounting for about two-thirds of industrial production). Smaller industrial enterprises are widely thought of as being easier to privatize. Similarly, the privatization of agriculture and small commerce should face smaller hurdles, and furthermore the problems (for instance, the channeling of credit to those activities) are quite different from those attached 
to large industrial groups. Last, this paper does not address the start-up of private enterprises.

While the analysis will be conducted in general terms and will not try to confront country specific issues, it is not meant to apply to the case of (former) East Germany, which faces an environment substantially different from that of the rest of EE.

\subsection{ORGANIZATION OF THE PAPER}

Sections 2 and 3 offer brief recaps of some essential features of private incentives and government intervention in western economies, in order to later ask which of these features can carry over to the EE environment. Section 4 describes the institutional and sequencing specificities of the EE environment. Section 5 draws the general implications of these specificities and thereby defines a minimal set of desirable properties of privatization proposals. Section 6 summarizes the main conclusions. Appendix 1 describes a scenario that satisfies the above properties and Appendix 2 discusses the reasonableness of its institutions and incentives. The purpose of these two appendices is not to formulate policy recommendations, but rather to clarify the discussion of Section 5. Last, Appendix 3 compares the situation of EE firms with that of growth firms in western economies.

\section{The Wheels of Western Economies: Institutions and Incentives}

Our economies are extremely complex institutions. It would be presumptuous to describe them in a few pages. But it is useful to recall some of their main features. ${ }^{8}$

\subsection{INSIDERS' INCENTIVES}

The separation of ownership and control requires specific incentives for the alignment of managers' and shareholders' interests. Because of the large scope for waste, much attention has been paid to the design of managerial incentive schemes. Several imperfect mechanisms combined together keep managers under some control.

- Earning based incentives. Managers generally receive bonuses based on accounting data (income, profit, output). Bonuses are more effective in fairly noiseless environments, as they then reflect managerial inputs accurately.

8. We include few theoretical references in this section and the next. See, for instance, Holmström and Tirole (1989) for some other references. 
- Stock market monitoring. Accounting data do not measure increases in the value of assets (and, if they react to investments, they do so negatively when investments are incurred). Stock market analysts acquire information about the value of the firms' assets, and the stock price conveys information about managerial investments beyond that revealed by the realized stream of future profits (because the stock price is an expectation of future profits and therefore yields a picture of the firm not yet garbled by future uncertainty). Stock prices can be used explicitly or implicitly for managerial control. A substantial fraction of managerial compensation in large U.S. corporations is in the form of stocks and stock options. Like bonuses, stocks and stock options work better if the measure is not polluted by large exogenous uncertainty about the firm's cost and demand. Stock prices can be used for managerial control implicitly as well. Indeed the managers of large German and Japanese corporations receive little stock based compensation relative to their U.S. counterparts, but the board of directors or banks may condition the managers' tenure or discretion on how well their firm's stock performs. We come back shortly to the role of stock markets as most proposals have advocated their use in EE.

- Relative performance evaluation. The informational value of accounting and stock data can be improved by comparing the performances of managers of firms facing similar environments. ${ }^{9}$ Relative performance evaluation (also called yardstick competition) filters out some of the noise on managerial performance measures.

- Board of directors monitoring. The firm's directors are meant to check on managers and have fiduciary duty to shareholders. There have been doubts about their ability to intervene other than by firing managers, about their incentives and ability to obtain information about the firm, and about their independence relative to management. ${ }^{10}$ Recent developments in the United States seem to have created more incentives for supervision, but boards of directors are still very imperfect monitors.

- Takeovers. Takeovers have been an important element of the corporate picture of the United States in the 1980s. Their role has been less important both historically and in countries such as Germany and Japan. ${ }^{11}$ Takeovers are meant to discipline managers by replacing them

9. Gibbons and Murphy (1990) find evidence that implicit compensation of U.S. chief executive officers (the revision in their pay and their probability of remaining in their position) is negatively and significantly related to industry performance.

10. See Mace (1971) for a negative assessment of the activity of boards of directors.

11. Hostile takeovers are almost unheard of in Japan. In the United States, in 1986 (an alltime record), 40 of the 3300 takeover transactions were hostile tender offers. It is difficult to measure the indirect effect of takeovers on voluntary transactions (Jensen, 1988). 
if they are incompetent or else if they shirk (build empires, etc.). Managers may care about retaining their jobs because they derive private benefits from running the firm or because dismissal imposes humiliation and relocation costs and endangers future job prospects. Raiders are meant to substitute for boards of directors that either do not monitor the firm closely or else collude with top management. The limits of takeovers are well known, both in terms of managerial incentives (they induce managerial myopia) and in terms of the difficulty for raiders to prevent free riding by current shareholders. ${ }^{12}$

- Bankruptcy and debt. Like the threat of takeovers, the threat of bankruptcy may make managers worry about losing control or their job. Also, in less dramatic circumstances, debt may still lower the managers' discretion by preventing them from using retained earnings to finance new investments and forcing them to go back to the capital market instead.

- Labor market monitoring: career concerns. Managers have reputations and want to convince the labor market that they are efficient. ${ }^{13}$ Outside job offers usually increase their salary whether they accept these offers or stay in the firm. Career concerns thus induce managers to behave better. Such concerns are stronger for young managers, although top managers may still hope for future appointments to boards of directors. They also are stronger for managers who frequently interact with outsiders, because external learning about managerial talent is what puts pressure on the manager's internal compensation.

\subsection{WHAT DO STOCK MARKETS DO?}

The stock market is alleged to fulfill several functions.

- Risk sharing. A risk-averse entrepreneur may want other economic agents to bear some of the risk associated with a risky project. Issuing stock is one way to do so. The risk sharing explanation for stock markets, however, only goes so far, as there are other methods to spread risk (e.g., through insurance markets or through claims closely held by a well diversified financial institution).

- Guiding investment. Another well-known motivation for a stock market is that the firm's and the aggregate stock prices convey information about the firm's future profitability and thus help select the right amount of investment. This motivation is not very convincing. Managers are likely to possess at least as much information about investment

12. See Grossman and Hart (1980) and Shleifer and Vishny (1986) for discussions of how free riding can be partly avoided.

13. See Holmström (1982). 
opportunities as the firm's outsiders, and when one further accounts for the noise in the stock price, it becomes doubtful that managers would learn much about the profitability of their investment from looking at their firm's stock price. The informational content of aggregate stock indices also seems limited in an economy where agents can learn about aggregate activity from national income and investment data, interest rates, bond prices, etc.

In our view, the specificity of the stock market is its role in collecting information about firms and in acting on this information. ${ }^{14}$ This view underlies much of the analysis in Section 5 and the Appendices.

- Measurement of the value of assets. We noted earlier that it is difficult to measure asset value and to give managers explicit or implicit incentives to invest in the absence of a stock market. Stock market analysts collect "speculative information," that is, information that helps predict future profits of the firm. This information does not alter future profits, but it helps in measuring managerial activity and is useful for incentive purposes.

- Increase in the value of assets. Stock market participants may also collect "strategic information," that is, information that brings new ideas for management (or about the desirability of removing the existing one) or unveils synergies with other firms. In other words, strategic information is information that, if acted on, increases the firm's value. It differs from speculative information also in that it is useless to its proprietors unless it is acted on by the firm, while speculative information can benefit its proprietors independently of a change in management or control.

\subsection{INCENTIVES OF STOCK MARKET PARTICIPANTS}

We just argued that the stock market supplies information that helps discipline management and increase profit opportunities. This information does not come for free. Besides the costs of transacting and those of regulating the participants' behavior, stock markets make heavy use of highly qualified and well-paid analysts. Ultimately these costs must be borne by the firms' owners. The stock market institution implies that the participants are rewarded by trading shares. (We would warn the reader that what follows is a very orthodox or "rational" view of the stock market. This view seems warranted because we will later argue for gradualism in the introduction of such a market. It is therefore appropriate to build the best case for stock markets.)

14. The following discussion and that of the next subsection borrow from Holmström and Tirole (1990). 
The major obstacle to analysts' taking advantage of their acquired information is the so-called "no trade theorem": Rational traders, who are risk neutral and value realized profits equally, ought not to trade simply on the basis of differences in information. In such "zero-sum game" markets, any gain by one is a loss for the other, and all traders cannot rationally expect to gain by trading. Hence trade should not occur if traders can hold on to their share. Another version of this extreme implication of the "lemons" problem is the celebrated free-rider problem. Suppose that a raider envisions an improvement in the way the firm is operated and wants to take over the firm to implement this change. To make money the raider must buy at a price below the firm's value after the improvement is made. Realizing this, current owners are better off holding on to their shares, so that the raider may be unable to take over the firm.

In practice, we observe both day-to-day trading as well as occasional takeovers. Economic theory has suggested explanations for both. Holders of speculative information make money because of the existence of liquidity traders, i.e., individuals who enter the stock market or exit when buying a house or facing a medical emergency, or institutions that follow rules or legal requirements for diversification. These liquidity traders lose money on average over their trades with the speculators.

To explain the acquisition of strategic information and takeovers, theory has suggested first, that the raider can dilute the firm's assets somewhat, and, second, that even in the absence of dilution big shareholders have an incentive to search for strategic information because they at least enjoy the increase in value of the shares they hold before the takeover (or the proxy fight).

Because we will later discuss ownership structures, we ought to mention the relationship between ownership concentration and the stock market incentives to acquire speculative and strategic information. Participants have many incentives to acquire information about the firm's prospects in a "liquid market," that is a market with dispersed, liquidity traders. (Note that there is no presumption that it is socially optimal to create liquidity by "offering liquidity traders as sacrifices." But this is an easy way to create liquidity.) In contrast, stock market participants have little incentive to acquire speculative information when facing large and stable owners. On the other hand, concentrated ownership may favor the acquisition of strategic information, as the raider derives more gains from bargaining with a single owner, say, than from facing dispersed, free-riding owners.

It is important to emphasize the role of large participants in collecting the two kinds of information. As was recognized long ago, people's 
capitalism with direct control of small shareholders over firms is an illusion. The costs of obtaining detailed information about a firm or industry vastly exceed the gains most citizens can expect from it. People's capitalism can at best exist through large institutions (mutual funds, pension funds, insurance companies, banks, etc.) holding their savings and being given adequate incentives to use them properly.

Last, we should note that acquisitions also serve to allocate productive units to their best use. As for any economic good, wrong prices may induce misallocation of ownership rights. For instance, a firm may take socially suboptimal control of another firm if the former has information that the latter is undervalued by the market. This adds to the general point that stock markets are likely to function better when the firm is not subject to large exogenous uncertainty.

\section{Some Market Structure Issues in Western Economies}

\subsection{MERGERS AND DIVESTITURES}

It is well known that concentrated ownership in an industry has the potential to raise consumer prices and reduce welfare. And, although the net effects may be smaller, vertical integration may also have anticompetitive implications by foreclosing access of buyers to suppliers or of sellers to outlets. ${ }^{15}$

There are two (complementary) ways of preventing excessive horizontal and vertical integration. First, the antitrust statutes often require an acquirer to report a prospective or actual merger to a merger commission who can then challenge it. ${ }^{16}$ Alternatively, the government (or private parties) can challenge integrated firms ex post and ask for divestiture.

The evidence is that it is easier to prevent mergers than to break up firms. Several cases of divestitures (such as the AT\&T 1984 settlement) have involved long and costly processes. [A current case of horizontal and vertical divestiture is that of the British Electricity system (see Vickers and

15. See, e.g., Hart and Tirole (1990).

16. In the United States the Hart-Scott-Rodino Act (1976) requires firms with assets or sales over $\$ 100$ million to report all proposed acquisitions of assets valued over $\$ 15$ million to the Department of Justice and the Federal Trade Commission. These agencies, who share the mergers evaluation, must react within some period of time (30 days, plus the possibility of a second request for information) or let the merger be consummated (see, e.g., Posner and Easterbrook, 1981, pp. 25-26, for details). This act reflects the philosophy of Section 7 of the 1914 Clayton Act according to which monopoly power must be thwarted in its incipiency. Similar rules exist in other countries. The European Court of Justice enforces articles 85 and 86 of the European Community competition law (concerning restrictive agreements and abuse of a dominant position) by making agreements that violate those articles (such as anticompetitive mergers) null and void. Firms must notify the European Commission to obtain an exemption. 
Yarrow, 1990b). Interestingly enough, the break-up is taking place before privatization.] Investigating the asymmetry between ex ante and ex post government intervention into market structures is outside the scope of this paper. Part of the asymmetry may result from the merged firms mixing up their activities to make future break-ups more difficult. Whether such behaviors have taken place in environments lacking merger laws is unknown to us. We take the asymmetry for granted and point at its consequence for EE: Any privatization before competitionoriented restructuring is likely to have a long-term impact on market structure in those industries that are not obviously competitive and will be somewhat protected from foreign competition.

\subsection{REGULATION ${ }^{17}$}

Because regulation or public ownership is likely to prevail temporarily in some industries and more permanently for natural monopolies (e.g., gas, electricity, postal service, railroads, and perhaps telecommunications), it is worth discussing a few key features of regulation that will be relevant in EE. We will not review here the various regimes regulating pricing and incentives (such as cost-of-service regulation, profit and cost sharing schemes, and price caps); we content ourselves with pointing out the general considerations in the choice of power of regulatory incentive schemes. The power of an incentive scheme is the fraction of (marginal) cost savings or profit increases retained by the firm. Regulation exhibits a basic trade-off between rent extraction and incentives. Incentives for cost reduction or innovation are best provided by high-powered incentive schemes, in which the firm's compensation is sensitive to its performance (an extreme example of such a scheme-the fixed-price contract - has the firm be paid a fixed amount and be residual claimant for its cost savings and profits). High-powered incentive schemes, however, leave substantial rents to the regulated firm. For instance, under a fixed price contract, any exogenous (technological) decrease in costs goes to the firm. Such rents are economically costly because they must be made up by distortionary taxation (if the government subsidizes the firm) or by distortionary prices or premiums charged to consumers (if the firm is required to balance its budget). Furthermore, popular pressure makes it politically difficult to sustain such rents. Very uncertain environments make it more difficult to extract rents and therefore require low-powered incentive schemes (such as cost-plus contracts in procurement or cost-of-service regulation). 
The choice of power of regulatory incentive schemes also impacts on the possibility of regulatory capture. Low-powered incentive schemes leave little discretion to regulators; for instance, the cost-plus contract "reimburse the firm's realized cost" does not make much use of their information. In contrast, high-powered schemes require substantial use of the regulator's information (for instance, to locate the socially optimal price to be paid to the firm in a fixed-price contract). They are thus subject to capture by interest groups, in particular the industry. Therefore countries where the threat of regulatory capture is particularly high should adopt low-powered incentive schemes for their regulated firms and public enterprises.

\section{The Eastern European Environment}

To understand how incentive structures must be tailored to the EE environment, it is convenient to describe its evolution as an initial noisy phase followed by a more mature phase. This division starkly highlights the two key specificities of the firm's environment in these transition economies: the extraordinarily high amount of uncertainty not controlled by the firms and the nonstationarity in its level. Needless to say, the various types of uncertainty will not resolve simultaneously, and the division into two phases is only an abstraction facilitating the analysis.

The first years of the drive toward market economies involve considerable economic, legal, and political uncertainty for firms:

- Cost uncertainty. The prices of inputs (labor, energy, raw materials, etc.) will be substantially modified. First, these prices are heavily distorted and will need to move toward yet unknown market prices. Second, the speed at which some of these inputs will be available is itself uncertain. For example, there are currently almost no accountants and lawyers trained to deal with modern corporations. Similarly it is hard to predict how fast entrepreneurial culture will pick up. Third, final market prices will depend on yet unknown governmental choices. For instance, the cost of labor will be influenced by policies concerning social security and unemployment insurance.

- Demand uncertainty. The demand for a firm's products will be unusually random in the years to come. It will depend on highly uncertain standards of living (themselves linked to, e.g., macroeconomic stabilization plans, lending by foreign countries, foreign exchange developments, and housing policies) as well as on the extent of restructuring (layoffs, bankruptcies, speed of foreign trade liberalization, etc.). 
- Financial uncertainty. Capital markets must be created from scratch. ${ }^{18} \mathrm{It}$ is hard to know how long it will take to develop institutions and to train investment bankers, analysts, and other financial experts. Another element of financial uncertainty is the treatment of interenterprise debts and arrears. ${ }^{19}$

- Legal uncertainty. It is widely recognized that legal changes related to property, contract, bankruptcy, antitrust, and labor laws ought to be introduced as soon as possible. The desire to tailor the laws to the EE environment as well as the sheer burden of drafting the laws are likely to delay their introduction.

- Political uncertainty. For historical reasons the ideology of future governments is more uncertain than in western countries. Consequently it is somewhat difficult to predict the tax structures and levels, the treatment of foreign assets and trade, the commitment to a hardening of soft budget constraints, the willingness to install a safety net, and so forth.

Another crucial feature of the EE environment is the need for a largescale competition- and efficiency-oriented restructuring. As previously mentioned, firms are highly integrated horizontally and vertically. Even ignoring competitive goals, massive break-ups and reorganizations of the industries will still be needed for efficiency purposes, as the current structure of integration reflects historical and political considerations more than any economic rationale. Input management will undergo substantial changes. With labor hoarding estimated at above one-half of the work force, many employees will be laid off (which requires the quick establishment of a safety net and retraining programs). Large inventories of inputs will need to be eliminated.

\section{Implications for Eastern Europe}

This section draws some implications of the brief discussion in Sections 2 and 3 for the EE environment reviewed in Section 4 . Appendix 1 will describe a possible scenario reflecting these implications.

\subsection{IMPLICATION A: STOCK MARKETS WILL WORK POORLY IN THE NOISY PHASE}

We contend that the conditions that make the trading of stocks a somewhat successful institution in western economies will not be present in

18. Existing banks are widely thought of as being unable to function in a market economy.

19. Interfirm credit is pervasive in EE. For instance, around $40 \%$ of the book value of the Polish companies to be privatized is in the form of outstanding liabilities from other enterprises (see Frydman and Rapaczynski, 1990). 
EE in the next few years. To see this, suppose that whatever policy is adopted leads to a somewhat liquid stock market and significant trading on this market.

Consider first the informational value of stocks for management control. There are several reasons why stock prices will very inaccurately measure managerial performance. On the one hand, price fluctuations will reflect the noise in the firm's environment more than the managers' value enhancement. The other side of the same coin is that stock market participants will focus on learning about government policy, and input, capital, and labor market developments more than on monitoring managerial activity. (Surely, this type of learning reduces the uncertainty about the firm's exogenous environment and allows better control of managers, but, as argued in Section 2, the cost of this reduction in uncertainty is eventually borne by the firm's owners.)

On the other hand, market analysts in western economies rely on (besides industry studies) the firm's income statements to forecast their future earnings. Analysts must work through income statements' depreciation and amortization to assess the economic value of assets, and must estimate future tax liabilities from their (distinct) tax counterparts; in so doing they must adjust for firm specific definitions of variables. Thus market analysis requires accounting structures that are reliable, undistorted, and relatively homogeneous across firms. It would be naive to expect these conditions to be met rapidly.

Still another reason to express doubts about a well-functioning stock market is that it will take time to set up an efficient system of financial regulation. For instance, it will be very difficult to fight insider trading without a modern system keeping track of transactions. Similarly, one would expect a fair amount of trading based on private information about forthcoming government reforms. It seems unlikely that a government that is engaging in so many reforms simultaneously will be able to introduce efficient financial regulation rapidly.

A final danger of active stock markets during the noisy phase is that garbled stock market prices may give the wrong signals for restructuring. For instance, the acquisition of one firm by another may be driven more by information that the former is undervalued than by the existence of synergies.

5.1.1 Corollaries of Implication A The first corollary is the need for a stable ownership of firms during the noisy phase. A stable core of owners is created, who hold on to their firms until the mature phase. We can consider several options in this respect. 
- Entrepreneurship. The firms are given to a small number of individuals who run them as entrepreneurs.

- Holding companies. This option creates an extra layer between firms and their final owners. A small number of holding companies own the firms, and they themselves are owned by all citizens. There are several variants on this, among them, mutual funds, privatization companies, investment banks, and banks. The distinction refers to what the holding company is allowed to do during both the noisy phase and the mature phase. During the noisy phase, investment banks and banks are indistinguishable. They receive deposits and hold debt and equity positions in the firms. Mutual funds and privatization companies are also alike; they do not receive deposits and are pure equity holders. During the mature phase, banks divest themselves of their equity, but continue to receive deposits and to make loans (they are thus banks in the American sense); investment banks keep some equity in the firms and are thus engaged in the same activities as during the noisy phase (they are thus banks in the German or Japanese sense). Privatization companies $^{20}$ divest themselves of the firms during the noisy phase and disappear thereafter. In contrast, mutual funds remain equity holders after the opening of the stock market at the beginning of the mature phase. (Note that, by not divesting equity, mutual funds are to privatization companies what investment banks are to banks.) For concreteness, and unless we specify otherwise, we will think of holdings as being mutual funds, i.e., as being pure equity holders during both phases. ${ }^{21}$ But we should keep in mind that there are some interesting variants on this.

- Public ownership. The State keeps control of the firms.

Each of these options can be accompanied by the distribution of non tradable, minority stakes to workers and management. We discuss them sequentially.

The first option (sometimes called "cowboy capitalism") has been recommended by some because it recreates the "robber barons" so prominent in the late nineteenth-century expansion in the United States. Its main appeal is that owners are directly involved in the firm's management, which alleviates agency problems. Despite this benefit, we find the option unappealing. Giving firms to entrepreneurs would be grossly

20. See Blanchard et al. (1990), Saldanha and Milanovic (1990), and Siebert and Schmieding (1990).

21. "Mutual fund" is actually a slight misnomer, because the term usually does not suggest a strong control over the firms, unlike what is envisioned here for the noisy phase. 
unfair. And one can have doubts about whether the distribution of income could be corrected through adequate taxes. Moderate taxation would leave immense wealth to a handful of lucky entrepreneurs who inherit healthy firms or firms with market power. On the other hand, steep taxation has its own limits. It is likely to induce entrepreneurs to dissimulate their income by (wastefully) transforming it into perks. And, more fundamentally (even if income diversion can be prevented), there are two issues concerning the design of an optimal tax scheme: the tax scheme should be tailored to the firm's environment (which brings taxation closer to regulation), and in this very noisy environment it will be difficult to design appropriate schemes that both give appropriate incentives for efficiency and extract entrepreneurial rents. (This point, although phrased in terms of the government designing an incentive scheme for the entrepreneur, is quite general. The proposal of creating robber barons is often couched in terms of giving property rights to some highly leveraged entrepreneurs. The motivation for having the entrepreneurs borrow against future profits is, like for the taxation scheme, one of fairness. However, the very noisy environment will make leverage a dangerous policy. Firms will have a high probability of bankruptcy; furthermore, the usual moral hazard problems - decapitalization, choice of very risky projects-associated with situations in which the firm is likely to be, but is not yet insolvent are bound to surface.)

The last two objections we have to the entrepreneurial solution are linked with the choice of the entrepreneurs. Even more than in western economies, there is little information about who is likely to be a good entrepreneur. Choosing the wrong person may have disastrous consequences for a firm (this issue will also have to be addressed for managers of holding companies). The other issue is that the large potential rents associated with becoming one of the happy few will politicize the appointment problem (this is also true for the appointment of managers of holding companies, but the rents are smaller so that capture of the appointment process is a bit less likely). We do not have a good scheme to select entrepreneurs in a rigid, nondiscretionary way. ${ }^{22}$

The creation of holding companies or their variants is meant to address the problems associated with entrepreneurs: in particular, the need to tailor incentive schemes to the firm's environment, ${ }^{23}$ to increase

22. Bidding for the right to become an entrepreneur would select former members of the nomenklatura (who own the wealth). On the other hand, competing on the basis of the amount of leverage one is willing to bear (instead of bidding an amount of money one is willing to pay up front to be an entrepreneur) will give rise to the agency problems analyzed in the literature on credit rationing.

23. Rausser and Simon (1991) argue that the firm's specificities should be reflected not only in the incentive schemes, but also in the very way it is privatized. They envision a 
the informational value of managerial performance, and design a mechanism to remove bad managers. The holding company in charge of monitoring a firm will have some incentive to create an incentive scheme appropriate to the firm, and to remove bad managers. And, very crucially, it will be managing a portfolio of firms. Even though the aggregate portfolio will be quite risky, it will be less so than the ownership of a single firm: by the law of large numbers, firm-specific shocks are diversified away. ${ }^{24}$ Also, the creation of roughly similar portfolios will enable incentive schemes to filter out some of the aggregate noise through relative performance evaluation among holding companies.

A serious concern with holding companies is that one creates an extra layer between the real owners of the firms (the citizens) and the firms. The problem of control of the managers of holding companies is a difficult, but important one and will be addressed later.

Last, public ownership, with government officials on the board of directors, will necessarily prevail before the firms are incorporated and privatized. It ought to be maintained a while longer in the sectors that need to be broken up before privatization.

Like those of the managers of holding companies, the incentives of the government officials to manage the firms efficiently during the transition period will need to be addressed. In particular, there is an important risk that the government be captured by the firms' employees. Labor hoarding is likely to remain, and wages to be way above market wages. An important difference with public enterprises of western economies is that, at least at the beginning of the noisy phase, there will be no obvious yardstick to compare the wages in the public sector to. Thus, government discretion concerning wages will be large and so will be the risk of capture.

To conclude the discussion of this first corollary of Implication A, we note that there is nothing new to the idea of creating a core of stable owners in a phase of uncertainty and restructuring. Stock markets have played a minor role in the early stage of the development of modern capitalism in the United States. For instance, a few investment banks (such as the Morgan investment bank) played a substantial role before the 1933 Banking Act separating commercial and investment banks.

hearing where the government would solicit information from intervenors in order to determine the method of privatization, the structure of access or control rights in the firm, etc. The holding-company method in contrast does not tailor the privatization process to the firm's specificities (beyond the fact that it falls in the large-industrialfirms category).

24. This argument is reminiscent of Diamond's (1984) description of the role of financial intermediaries. 
Banker control over railroad trusts was commonplace. ${ }^{25}$ Similarly, many of the utility systems were controlled by bank-related holding companies. Large "interest groups" such as DuPont, Mellon, and Rockefeller dominated the corporate scene. The idea of holding companies is to recreate similar conditions for restructuring without the distasteful implications for wealth distribution.

The second corollary of Implication A is that the firms' managers ought to be given low-powered incentive schemes. On the one hand, profits will be very garbled measures of performance. On the other hand, in the (shortrun) absence of a stock market, there is no measure of asset value and it is difficult to give managers explicit or implicit incentives to increase their firm's value. (One of course can give incentives to managers based on the stock value after the stock market starts functioning, but the role of such incentives is quite limited by the delay in measuring asset value, and by the noise and the reorganization of assets occurring in between.) The difficulty in creating long-term incentives adds to the case that short-term incentives based on the firm's profit (bonuses) should be limited: Managers who face primarily short-term incentives are prone to focus on current profits to the detriment of future profits (this effect comes on top of the reduction in the use of bonuses due to the high uncertainty about profits). So one is constrained to give low-powered managerial incentives across the board.

\subsection{IMPLICATION B: MOST COMPETITION-ORIENTED RESTRUCTURING OUGHT TO TAKE PLACE BEFORE PRIVATIZATION}

As discussed in Sections 2 and 3, the private sector may undertake efficiency-oriented restructuring, but it will not promote competition because this would reduce profits. And breaking up firms (horizontally and vertically) on the basis of antitrust laws has proved difficult in western economies and is likely to be a quagmire in countries without a tradition of antitrust enforcement. So it seems that competition-oriented restructuring ought to be undertaken before private ownership is introduced.

Competition-oriented restructuring of course need not affect all industries. Some will naturally attract a large number of firms and be fairly

\section{For instance,}

very often the railroad reorganization led to the establishment of voting trusts, with very important powers given over to three trustees for some term of years (typically five), partly to assure the security holders that responsible management would be in charge during the period of corporate revival. Investment banker domination of these voting trusts was commonplace.

(Herman, 1981, p. 118, emphasis added). 
competitive on their own. Others can be made competitive by the opening of the country to foreign competition. We should, however, not view foreign competition as a panacea for monopoly power. First, it can affect only tradables. Second, the government may be captured by industries or else be pressured by trade deficits, and may impose tariffs or other forms of protection. Third, some (at least temporary) protection is likely to be justified in some industries; while not starting from scratch, many firms cannot compete on the international market at this stage and will need some protection to develop to a healthy level (this is the infant industry argument).

The corollary of Implication B is, as we have already noted, that firms in industries that are potentially noncompetitive should be kept a while longer under public ownership before they are handed in to the stable private investors.

Clearly there will be no time to fine-tune the break-up of firms. Only the most obvious and simpler divestitures ought to be implemented. Needless to say, mistakes in evaluating synergies between units or future market conditions will be committed in such a short time frame. For instance, it may be the case that the merger commission (to be created) will later allow the reunification of units previously broken up, because this is needed to face foreign competition. Yet we would expect some major competitive gains to be obtained by some simple break-ups.

In our opinion, the main hurdle will be the government's commitment to carry out divestitures where these are needed. Pressures from firms' employees to keep the monopoly positions will be strong. The government may also be tempted to preserve the firms' monopoly power to make holding companies (or entrepreneurs, depending on the case) more successful financially (this might be the EE equivalent of western experiences of not breaking up monopolies in order to derive more revenues from privatization).

One possibility to deal with this problem is to create a divestiture commission that would be composed of (a majority of) independent government representatives and (a minority of) representatives of foreign lenders and donors, who would be advised by domestic and foreign experts and industry delegates without voting power. Linking, through moral suasion, foreign aid ${ }^{26}$ to a minimum effort to create competition might be an incentive for the government to undertake some competition-oriented restructuring. The government representatives could not be easily re-

26. In this respect, the foreign representatives need not necessarily belong to institutions engaged in micro projects (European Bank for Reconstruction and Development, International Finance Corporation) and could also belong to the World Bank, the IMF, USAID, or lending countries. Some merger experts from the U.S. Department of Justice or the European Commission might also be involved. 
moved by their government (as is the case for instance of justices on the U.S. Supreme Court ${ }^{27}$ ), and thus would be less subject to political pressure. The presence of representatives of foreign lenders on the commission might prevent some extreme decisions, and mainly would allow some monitoring of decision making.

\subsection{IMPLICATION C: THE THREAT OF CAPTURE OF GOVERNMENT DECISION MAKING BY INTEREST GROUPS IS, DURING THE TRANSITION PERIOD, MORE SERIOUS IN EE THAN IN WESTERN ECONOMIES}

Since at least Montesquieu and the American Federalists, it has been well understood that strong safeguards must be put in place to prevent governments from serving the interests of specific groups. Many of these safeguards did not exist under the previous regimes and will take time to install: organization and rotation in the civil service, administrative procedures and regulatory hearings, independent administrative courts, checks and balances in government, development of a tradition of investigative reporting by the media, etc. Furthermore, historical circumstances are likely to create a close relationship between regulator and regulated, similar to the one associated with the revolving door in western economies.

How will the threat of capture influence the transition process? We already mentioned the issue of the governments' commitment to domestic competition. The commitment to introducing foreign competition is also a serious issue. While the fragility of the industries seems to warrant some temporary protection, the process of trade liberalization may be captured and trade barriers never be removed. Protection, if any, should thus be accompanied with a clear, nondiscretionary time table for liberalization.

Another implication of the idea is that it may be dangerous to give the government control over the holding companies (during the noisy phase). (These companies would be regular joint stock companies traded on the stock market, or else would disappear, in the mature phase.) The government could then force the holding companies to implement demagogic policies in the firms they control or to induce those firms to collude on the product market.

Yet another implication of the idea is that regulated firms ought to be

27. A distinction to be made is that independent civil servants in western economies often have a long tenure. Because the divestiture commission is meant to be ephemeral, there is a danger that, despite their independence, government representatives might be pressured by their governments through the threat of bleak future job prospects. A possibility is that the members of the divestiture commission be reallocated later to the merger commission. 
subject to low-powered incentive schemes, which as we saw in Section 3 create little scope for discretion and thus capture.

Last, there should be a timetable for the privatization process to which the government would be committed. All its steps should be simple and clearly defined. ${ }^{28}$ Overall, the corollary of Implication $C$ is thus that one should pay attention to the discretion left to regulators.

\subsection{IMPLICATION D: THE MAIN ATTRACTION OF FOREIGN AID FOR THE TRANSITION PROCESS MAY NOT BE EXPERTISE, BUT RATHER COMMITMENT AND INDEPENDENCE FROM INTEREST GROUPS}

Governments and private sectors can use the aid of international donors and lenders to hire foreign expertise by themselves. The experts may be, but need not be supplied by the donors and lenders. A more specific attraction of foreign aid is that foreign institutions are likely to be freer than governments from capture by domestic interest groups, and it may well be that some amount of their involvement in the reform process would commit the countries to a right course of action.

Certainly, foreign involvement raises a familiar dilemma. The foreign donors and lenders are themselves not always free from pressure from the governments that finance them. Furthermore, they may push their internal agenda rather than the most appropriate policy for the country. There is thus a danger of relinquishing national sovereignty to foreigners. Some arrangement has to be found in each instance that preserves national sovereignty, and yet uses foreigners as partial safeguards against capture.

Let us mention two other cases in which foreign institutions might be used as a commitment device. First, they might be given voting rights (with possibly no claim to income) in boards of directors of holding companies. Other members of the board would be government representatives and delegates of shareholders (the citizens). Giving minority stakes to each of the three groups preserves national sovereignty; it also raises the possibility that the foreign institutions make the case for efficiency in board meetings and influence the possibly less experienced and informed delegates of shareholders.

Second, those international financial institutions that directly lend to the private sector (as will be the case for the European Bank for Reconstruction and Development, and is the case for the International Finance Corporation) may be used as a commitment to harden the firms' soft budget

28. By "simple," we mean "not informationally demanding." For instance, a regulatory rule of the type "charge marginal cost" looks simple, but is extremely complex to implement because it requires cost information that is hard to obtain. Informationally demanding rules give discretion to regulators and are prone to capture. 
constraint during the noisy phase. Firms will need financing for new projects and maintenance. The financing by domestic banks, whether public or private, raises some problems, besides the fact that the banking system is not well developed and is in financial distress in some countries (including Poland). Public banks are likely to adhere to the longstanding tradition of the soft budget constraint. The government has an incentive to cede to managers and employees afraid of losing their jobs, and rescue insolvent banks and firms, leaving painful restructuring to future administrations.

The use of private domestic banks (without equity holding) raises the issue of their regulation. The large aggregate uncertainty makes insolvency of a substantial fraction of banks a real possibility. The threat of insolvency together with the prospect of being bailed out in case of trouble gives rise to moral hazard, with the banks continuing to lend to financially troubled firms in the hope things will get better in the future, and more generally engaging in risky projects. (The regulatory slippage in the United States in the 1980s illustrates how financial regulation can go awry even in a country with a long experience in the matter. The savings and loans were subjected to new and looser regulatory accounting principles and to lower capital requirements in order to allow insolvent institutions to continue. The hope was that they would recover and the motivation was to reduce immediate political costs.)

Financial regulation is no easy matter. To discourage excessively risky investment, one ought in theory to subject savings institutions to "riskbased capital requirements," with the requirements based on the estimated value of assets in different economic scenarios and being continuously adjusted. Even western economies are reluctant to adopt such flexible financial regulations because of the burden they impose on regulators, and because of the substantial discretion conferred on them. It is quite difficult for regulators to estimate risks appropriately, and it is easy for them to misreport actual risks. One may have some doubts about the efficiency of banking systems in the near future for countries lacking a tradition of financial regulation.

The issue seems to be to find a way to give lenders an incentive to monitor firms and to stop financing them when they become insolvent. Such considerations should come to mind when defining a role for the EBRD. Will the EBRD have such an incentive? Should it play the role of a merchant bank, taking only minimal stakes itself and bringing in loans of private foreign investors? If it plays the role of a merchant bank, should it guarantee the private loans, and, if it does so, would not the lack of incentives for private foreign debt holders to monitor firms justify centralizing loans and have the EBRD be the only lender? Or should the 
interests of private foreign debt holders be subordinated to the interests of the EBRD to give them an incentive to monitor? These are a few of the questions to be addressed here.

A conjecture is that the best use of foreign financing is debt rather than equity. Financing by domestic banks creates the two problems of commitment and regulation, which suggests some substitution by foreign loans. (A distinct motivation for foreigners lending rather than taking equity positions is that it would face a lower opprobrium in the EE countries.)

\subsection{IMPLICATION E: THE STOCK MARKET MUST BE APPROPRIATELY INTRODUCED AT THE BEGINNING OF THE MATURE PHASE}

Even after the legal framework (ownership, contract, bankruptcy, antitrust laws, disclosure rules, etc.) is put in place, and professionals (auditors, analysts, managers, and so on) are trained, the stock market will not run smoothly overnight. We saw in Section 3 that the liquidity for the stocks is what creates an incentive for analysts to estimate the firms' values and to discover synergies. We would expect little liquidity in a stock market restricted to holding companies. ${ }^{29}$ On the other hand, opening stock markets to individuals, to newly created firms and institutional investors, and possibly to foreigners is likely to create such a liquidity. While the final objective is to give wide access to stock markets, we must think about the consequences of immersing small investors directly into a market where stock prices have never been quoted. Big investors will be needed to invest in acquiring information about real market values. Sophisticated small investors, who will be unable to obtain detailed information, will be reluctant to trade with the informed big investors in the presence of such uncertainty about true values, as they are likely to lose their shirts. On the other hand, unsophisticated small investors (and there are likely to be many at the beginning given the lack of experience with stock markets) may not realize the risk they face. They would be the ones to create liquidity in the market. This goes against fairness and against the building of a popular trust and political support for the stock market institution. Furthermore, liquidity trading would create noise in the initial pricing of stocks (as it does in all stock markets).

5.5.1 Remark An interesting parallel is that of a primary initial public offering by a company not yet quoted on the stock market. ${ }^{30} \mathrm{~A}$ company

29. Once bilateral trades of assets to achieve synergies have taken place, it is not clear why holding companies should trade among themselves. The gain for one becomes a loss for the other, as discussed in Section 3.

30. See, e.g., Brealey and Myers (1988, pp. 329-332) for a description. 
that goes public in general selects an underwriter and both agree on an issue price. The registration statement submitted to the Securities and Exchange Commission (in the United States) as well as presentations to institutional investors convey information to potential buyers. It is interesting to note that potential buyers are usually big, sophisticated buyers when the firm goes public and when therefore no previous price information can be reflected in the current price.

In contrast, initial public offerings associated with the privatizations in western economies (in the United Kingdom and in France, for example) have tried to reach small investors through substantial discounts [they also devised schemes to allow employees to buy shares in their firms on favorable terms - see Vickers and Yarrow (1990a) for a description of this in the case of the United Kingdom and Chile].

The problem of inception of the stock market in EE (under the corollary of Implication A that firms are controlled by a stable owner during the noisy phase) seems to be closer to that of U.S. firms' going public than to that of U.K. state-owned enterprises being privatized, and this for two reasons: First, the number of firms to be privatized is much larger than in the United Kingdom (the United Kingdom privatized only a dozen big firms in 10 years); second, the design of the inception of the stock market must take into account the incentives of the firm's private owner before the stock market opens. ${ }^{31}$

There are several ways to introduce the stock market. For instance, one can let the holding companies, and possibly foreigners, bid for firms at the beginning of the mature phase, with the proceeds of the auction going to the previous owners of the firms; the stock market would later be opened to the general public once prices have stabilized. To create some liquidity, one might for instance force the holding companies to divest some of their shares.

This brings us to a discussion of what goals the inception of the stock market in the mature phase must meet. Here are some desirable properties of associated auctions:

1. Generate information about firm value: the auction should yield a picture of asset value. This information is useful for assessing the relative performance of holding companies during the noisy phase as well as to set up appropriate incentive schemes for the firm's managers for the mature phase. As discussed above, little information will

31. But there are also differences with initial public offerings of private companies. For instance, agency problems before the offering are less serious when only the entrepreneur and possibly a venture capitalist are involved than when the firm belongs to a holding. More on this in Appendix 3. 
be generated by the illiquid market created by voluntary sales by the holding companies. A possibility is to set aside a fraction $\alpha$ of the shares of each firm of each holding to be sold at the inception stage, and on which the owning holding company is not allowed to bid. ${ }^{32}$

2. Create an appropriate structure of control with large, but not dominant shareholders. ${ }^{33}$ One possibility for this is to set $\alpha>0.5$, and prevent any bidder in the auction from acquiring a majority of shares himself. ${ }^{34}$

3. Give incentives for holdings to monitor and invest during the noisy phase: Because the value of the firm's assets is partly reflected in the bids at the inception stage, giving the proceeds of the auction to the previous owner yields incentives to invest. However, it may be useful to let the holding keep a minority share in the firm $(\alpha<1)$ to give it further incentives to invest. ${ }^{35}$

4. Prevent cartelization: The selection of allowed bidders (other holdings, other domestic and foreign firms) should prevent the creation of interlocking directorates that would create horizontal collusion or vertical foreclosure in concentrated industries.

\section{Summary}

We argued that two key specificities of the EE transition process are the unusually high level of uncertainty in the firms' environment and the nonstationarity in its level. From there followed our main points:

32. There is a large literature on "common-value auctions" with information acquisition, that ought to guide the design of such auctions (e.g., Milgrom, 1981; Lee, 1982; Matthews, 1984). This literature has looked at simple auctions, in general the first-price auction, and derived equilibria (Riley, 1988, allows the winner's price to depend on the other bids and on the stock's future performance and might be particularly relevant here). A recurring theme of this literature is that bidders acquire too much information from a social viewpoint. This conclusion comes from the assumption that the information has no other role than redistributing income, which is the case if the value of the stock is exogenously given. Here, the information revealed by the auction has social value because it helps measure the previous owner's performance and initialize the managers' stock incentives. New theoretical work in this area linking ex post auctions with ex ante incentives would be most welcome.

33. The market may perform such an adjustment itself after the auction stage. The idea behind avoiding the formation of majority shareholders is to limit the need for costly controls to prevent minority squeeze outs following the auction.

34. Effective control may require less than $50 \%$, depending on the distribution of shares.

35. Laffont and Tirole (1988), building on ideas in Williamson (1976), study the issue of investment in a repeated auction context, and show that to promote unobservable investments, the incumbent firm should be favored at the renewal stage and that the power of his incentive scheme should grow over time. See also Stein's $(1988,1989)$ related work on managerial myopia. In the context of an auction with information acquisition, investments are partially, but not fully observed by the potential bidders. 
1. Stock markets cannot function well during the noisy phase. The large amount of noise as well as the absence of trained analysts and reliable accounting data will deprive stock prices of most of their information content. The EE environment seems to call for hands-on monitoring by a stable ownership.

2. Managers of firms and holdings must face low-powered incentive schemes during the noisy phase, which raises a concern about efficiency. Alternative incentive mechanisms must be devised: e.g., close monitoring of firms by holdings and of holdings by independent directors, relative performance evaluation for holding managers and holding directors, and career concerns for all.

3. Because of the asymmetry between preventing mergers and breaking up firms, market structure interventions to prevent horizontal collusion and vertical foreclosure are best performed before privatization. A divestiture commission ought to be given incentives (in particular be free from interest group pressure) to rapidly perform break-ups in those industries where anticompetitive behavior is a concern.

4. Regulated firms should be given low-powered incentive schemes during the noisy phase to limit the level of rents as well as to respond to the high threat of regulatory capture. Incentives should be raised during the mature phase.

5. Because privatization ought to occur before the introduction of a stock market, specific plans must be made for the inception of the stock market, that reflect the considerations discussed in Section 5.5.

The purpose of this paper has not been to formulate precise policy recommendations. Besides the fact that our theoretical understanding is still limited, policy recommendations should be tailored to the industrial and political realities of each country. The issue is not only to quantify the various parameters of the theoretical analysis-e.g., the likely length of the noisy phase, the number of holdings, or the list of industries with potential market structure problems. It is also to adjust the theoretical framework to account for further fairness considerations, for the political economy of commitment or for the difficulty in regaining control over firms, ${ }^{36}$ depending on the country's specificities. The scenario developed in Appendix 1 must be viewed in the light of this comment. It sole purpose is to further clarify and refine the analysis of Section 5 and not to design a ready-to-use proposal.

36. See Dewatripont and Roland (1990) for interesting considerations on the means to obtain political support for a reform and on some commitment aspects of reforms. 


\section{APPENDIX 1: A SCENARIO}

The purpose of this appendix is to examine a scenario involving holdings, that is consistent with the implications of Section 5. Appendix 2 discusses the incentives inherent to this scenario and some of its drawbacks. Appendix 3 points at the analogies and differences of the associated governance structure with that of growth companies.

We break each phase into "subphases" or "periods":

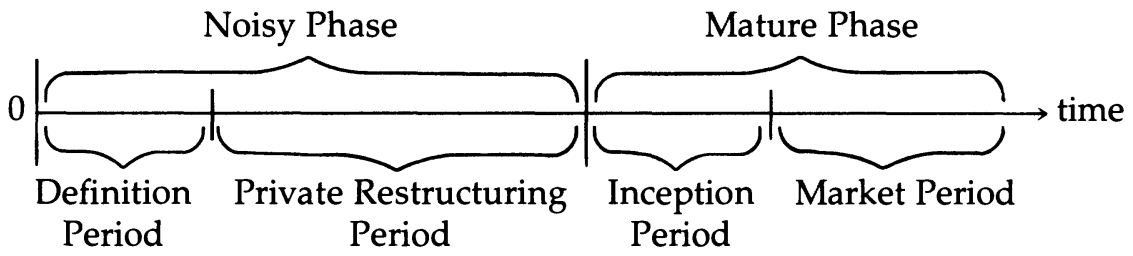

\section{Definition period}

This period, among other things, reallocates capital.

1. A divestiture commission is created with independent representatives of government and representatives of international institutions on its board, assisted by domestic and foreign experts. The commission will perform the most obvious cases of competition-oriented restructuring.

2. Firms are renationalized, and then divided into three groups by the divestiture commission. The first group consists of the firms in naturally competitive sectors or in sectors in which foreign competition will not substantially hinder the growth of firms. These firms will be allocated to holding companies as soon as possible. The second group consists of firms that will need to be broken up by the divestiture commission before being handed to the holding companies at the end of the definition period. The third group is composed of natural monopolies and will either remain under public ownership, or else be transferred to the holding companies and remain regulated in the long term.

3. A safety net is created to protect workers from the hardships created by the forthcoming private restructuring period.

4. The main elements of property, contract, bankruptcy, and antitrust laws are enunciated and put into operation.

5. Holding companies are created and incorporated. 
The number of holding companies depends on country size and available expertise. It must be large enough to obtain effective monitoring of the firms, to limit the holdings' political power, and to avoid interlocking directorates of firms in tightly oligopolistic industries (see below). But it must be small enough for the holdings to own similar and diversified portfolios. ${ }^{37}$

The shares of a holding company are distributed freely and equally to all citizens but will not be traded before the mature phase. ${ }^{38}$ The holding company's board of directors includes representatives of the government, of international institutions, and of the shareholders (all with minority voting rights) ${ }^{39}$ Directors have fiduciary duty and, like the holding company's managers (see below), are rewarded with stocks, with a strong element of relative performance evaluation.

The board of directors selects the holding companies' managers, and puts them on an incentive scheme. During the noisy phase, managers of the holding companies receive a salary. At the inception period, they are rewarded on the basis of the absolute performance of their holding company (through stock options) and, more importantly, through the performance of their holding company compared to the average performance of other holding companies. Low-powered incentive schemes, i.e., small stock options, seem appropriate. The main incentives for the

37. A small number of holdings implies a large number of firms per holding and, possibly, reduced monitoring of each firm. On the other hand, holdings should be given similar portfolios to be comparable; increasing the number of firms per holding improves comparability by reducing on average the ex post inequities in the distribution of firms to holdings. To accommodate these two goals, the holding companies might not be given firms in all industries but rather specialize in a subset of industries. Their performance would then be compared with that of holdings with similar portfolios rather than with that of the average holding. Alternatively, one could have holdings own firms in overlapping subsets of industries, and design more complex relative performance evaluations to enlarge the comparison group.

The concern about the holdings' political power relates to the existence of a few powerful groups with congruent interests. The congruence of interests is in part created by the desire to set up comparable portfolios.

Yet another consideration that may be relevant to the choice of number of holding companies is that there should be enough of them in order for incentive schemes based on relative performance evaluation not to lead to perverse incentives (with two holding companies, say, beating on the other holding company may become a goal in its own right, while with many holding companies, a holding company cannot affect the average performance of the others much).

38. The distribution of shares can await the mature phase as the plan is not to create an active stock market before then. It may still be the case that a secondary market opens during the noisy phase with the private sector exchanging options on the shares to be distributed. We would still expect trade to be substantially smaller in the noisy phase than if a regular market existed for the shares.

39. Because of the scarcity of trained private-sector businessmen, representatives of shareholders might be former members of the controlling ministries, professors, or the like. 
holding companies' managers during the noisy phase, besides relative performance evaluation, are career concerns and monitoring by the directors. The managers can be fired by the board of directors, in which case they receive only a fraction of the final reward at the inception period equal to the length of their tenure in the holding company divided by the total length of the noisy phase. ${ }^{40}$

The holding companies are endowed with the shares of the firms to be privatized (in the middle of the definition period for the firms that do not need to be broken up, and at the end of the definition period for the others). There are two variants: (1) Each firm is allocated to a single holding company, and 2) each firm is shared among several holding companies. We will consider the first variant for concreteness. ${ }^{41}$ (As mentioned in the text, one can also consider a situation where holding companies are debt as well as equity holders. For simplicity, we develop the case of pure equity holding in more detail.)

Firms are allocated randomly to the holding companies to avoid capture as well as to roughly equalize the initial quality of portfolios among holding companies. In tightly oligopolistic industries with little prospect for intense foreign competition, firms are allocated to holding companies so as to prevent common ownership of product market competitors. Similarly, where there is a danger of foreclosure, common ownership of a vertical structure is avoided.

1. The managers of the firms are given employment contracts. Bonuses, stock options, and relative performance evaluation are limited by the large aggregate and idiosyncratic uncertainty and by the fact that the firms may divest themselves of assets or receive assets from other firms of the same or another holding company. Where the reallocation of capital across firms proceeds quickly, the managers can be given some stock options and bonuses linked to the performance of their firm. ${ }^{42}$ The main incentives for the firms' managers during the

40. This is to guarantee that firing managers does not per se increase shareholders' wealth. In western economies, managers often exercise their stock options when they quit or are dismissed. But they cannot do so in this scenario because the stock market is not yet active in the noisy phase.

41. Giving a firm to a single holding company prevents free riding in the monitoring of the firm. Giving it to several holding companies may increase the diversification of the portfolios of the holding companies; it also may offer a diversity of views and prevent disastrous reorganizations brought about by a single, incompetent team.

42. There is an argument for focusing on "external restructuring" first so as to create welldefined entities quickly. Managers will be somewhat reluctant to perform the "internal restructuring" (elimination of labor hoarding, reorganization of management and production processes, etc.); defining the boundaries of the firm early will make them more responsible and will allow small monetary incentives to complement monitoring. 
noisy phase are career concerns and, especially, monitoring by the holding companies.

2. Regulation of public enterprises and private regulated firms is as in the private restructuring period (see below).

3. A merger commission is created (possibly the divestiture commission becomes the merger commission after having broken up firms).

\section{Private restructuring period}

1. Holding companies restructure firms: They make sure that labor hoarding is eliminated and that insolvent firms are shut down. They reallocate capital and eliminate inefficient vertical integration. They monitor the firms' managers in their attempt to organize production efficiently.

Holding companies may sell units or firms to one another subject to the approval of the merger commission when they have assets in the same industry. The sale of assets may be used by the holding companies to purchase other assets or may be invested in indexed bonds. ${ }^{43}$

2. The government completes the legal system.

3. The government sets up agencies to regulate the banking sector and the stock market. These agencies will later prevent insider trading, enforce disclosure and conflict-of-interest rules, monitor savings institutions, etc.

4. The government sets a timetable for trade liberalization and defines foreign exchange guarantees for the capital inflows. ${ }^{44}$

5. Firms put modern accounting structures in place.

6. Borrowing: The EE industries will need money for updating current technologies and for financing new investments. First, they may borrow western capital (from private lenders as well as from international institutions). As we noted earlier, the comparative advantage of foreign participation might be loans rather than equity holdings because of the commitment and regulation problems associated with financing by domestic banks. Furthermore, foreign equity financing is likely to be restricted on political grounds anyway. Because the EE economies will need substantial inflows of capital from western economies, ${ }^{45}$ it seems natural that privatized firms look abroad for debt holders.

43. Alternatively, they could distribute dividends to the shareholders. An accounting system would then have to be devised that would keep track of dividends and compound them at the rate of interest so that the wealths of the holding companies can be compared at the inception period.

44. See Newbery $(1990 a, b)$ for a discussion of the sequencing of trade liberalization.

45. See, e.g., Frydman and Rapaczynski (1990). 
A second source of financing may come from private domestic savings (I do not have much feel for how large these private savings will be during the noisy phase). An interesting issue is whether one should allow holding companies to receive deposits and channel them to firms, in which case the holding companies would be similar to the U.S. investment banks of the early twentieth century.

Should the creditors (foreign and domestic) lend their money directly to the firms or indirectly through the holding companies? In the scenario considered here, with each firm controlled by a single holding, it would seem difficult to channel loans directly to the firms. A holding company would then have an incentive to strip some of its firms of their assets through low transfer prices for intermediate goods or physical assets charged to other firms of the holding company. ${ }^{46}$ To prevent this behavior, the holding company must be liable for its firms' debts, or, more realistically, the loans must be channelled to the firms through the holding company. (Such stripping of the firms' assets is more difficult, although not impossible, if the firms are held by several holding companies with minority shares. In this case, direct lending to the firms becomes a possibility.)

1. Each holding company hires or trains domestic and foreign analysts, who start studying the potential of the firms (not only the holding company's) that the holding company will be allowed to bid on.

2. Regulated private firms (owned by holding companies) are subject to cost-of-service regulation. The standard for cost of service is variable cost plus a fair rate of return on the investment sunk since the beginning of the process. No attempt is made to assess the rate base (amount of capital) before the beginning of the process. Thus prices only reflect new investments. Price reviews are frequent (every six months, say) in order to adjust to a rapidly changing environment. ${ }^{47}$

46. U.S. courts have long recognized that a corporation must have the authority to act in its own best interests to be identified as a separate corporation and be subject to limited liability in case of insolvency. For example, in a well-known case (Henderson et al. v. Rounds \& Porter Lumber Co. 99F. Supp 376, U.S. District Court, W.D. Arkansas 1951), a timber processor was forced to sell lumber at half the market price to a lumber company that owned half of its shares, and was led to insolvency. The judge ruled that the latter company was liable for the former's debts.

47. Not including historical capital into the rate base considerably simplifies the regulatory process. Yet cost-of-service regulation will not be a trivial exercise. Multiproduct firms will need to allocate common costs to each output according to some arbitrary, fully distributed cost accounting system. Other issues familiar from the regulation of U.S. utilities will surface: the choice of the rate of depreciation for new investment, the determination of allowable costs and that of a fair rate of return. 
Given that we have strong reservations about cost-of-service regulation in general, we will need to justify this regulatory recommendation in Appendix 2.

3. State owned enterprises are also subject to some form of cost-ofservice regulation. There are serious concerns about the management of these state-owned firms. For instance, the employees are likely to ask for high wages, which the government is likely to grant (this is a serious concern in private firms subject to cost-of-service regulation as well. But in those firms, the presence of private owners may alleviate this concern a bit). In a sense this problem is the same as that facing state-owned enterprises in western economies, but some of the safeguards there, like the benchmark of market wages in the private sector and the control of ministries in charge by independent general accounting offices, are much weaker in EE. Serious thought should be given to the creation of commitment mechanisms for disciplining state-owned enterprises.

\section{Inception of the stock market}

Holding companies, newly created firms, and institutional investors, and possibly foreigners ${ }^{48}$ bid on each firm. The proprietor of the firm receives the proceeds of the auction. Holding companies bid in units of currency. Those who have a negative balance after the auctions issue indexed bonds in the corresponding amount to the government. Those with a positive balance receive a corresponding amount in indexed bonds from the government. (Or else the holding companies balance their accounts among themselves.) Some constraints are put on the auctions:

First, a mechanism is set up to prevent interlocking directorates in tightly oligopolistic industries. ${ }^{49}$ For instance, in an industry with two large firms, a simple-minded mechanism has half of the holding companies bid on one firm and the other half bid on the other firm.

Second, to induce trade among holding companies and therefore to create incentives to collect during the noisy phase information about the firm's value, a fraction of each firm can be earmarked for holding compa-

48. There are arguments suggesting that foreign bidding will be limited, related to the deep-seated fears of a foreign takeover (Blanchard et al., 1990), to the threat of expropriation of foreign capital, and to the problems caused by the appreciation of the local currency brought about by a large sudden inflow of capital (as was the case in Chile).

49. In the United States, Section 8 of the Clayton Act (1914) prohibits interlocking directorates when these lessen competition substantially. 
nies that did not own this firm before (the holding companies resemble "privatization companies" if this fraction is equal to $100 \%) .{ }^{50}$

A holding company's total asset value after the auctions is the value of its shares in the firms, plus the proceeds of the sales of shares of the firms they used to own, minus the cost of purchase of shares of firms that belonged to other holding companies. The auctions have thus created an initial value for both the firms and the holding companies, which will enable other economic agents to enter (or exit) the stock market in a less uncertain situation for stock prices.

\section{Market period}

1. Immediately after the inception period the markets for the firms' and the holding companies' stocks are open to all: citizens (who can sell their shares of holding companies and buy shares of firms), foreigners (up to government restrictions), holding companies (up to laws on mergers and interlocking directorates enforced by the merger commission), and other participants. The holding companies' assets are thus now liquid.

2. The government and the (nonequity holding) foreigners lose their voting rights in the boards of directors of the holding companies.

3. Firms can issue equity and bonds and can borrow from (newly created) domestic banks.

4. The managers of firms and holding companies are presumably put on incentive schemes that are more powerful than those during the noisy phase.

5. Trade liberalization is completed according to the predetermined timetable.

6. Regulated firms are given more innovative and more powerful incentive schemes than cost-of-service regulation ("incentive regulation").

\section{APPENDIX 2: DISCUSSION OF THE INCENTIVES IN THE SCENARIO}

\section{Incentives of firms}

The prescription of very low-powered incentive schemes for managers of firms reflects the absence of a stock market as well as the large uncertainty

50. Setting aside a fraction for other holding companies is similar to a secondary public offering by a private company that looks to sell some of its existing shares. The remaining fraction gives rise to an auction in which the previous owner participates. 
about profits. Close monitoring by the holding companies is important at this stage. We would also expect managerial career concerns to play a role: During the noisy stage, there is much to be learned about managers both because managers lack experience running profit-oriented units and because previous education is often unrelated to (and therefore is a poor predictor of the ability in) the job. The labor market is thus likely to pay close attention to the managers' behavior, which gives managers incentives to try to fool the labor market by working hard. This career concern, however, will be operative only under two conditions: first, managers should be able to move easily to other jobs; second, the labor market must be able to differentiate the roles of exogenous shocks and of managerial contribution in determining managerial performance.

The prescription of giving more bonuses and stock options after the inception phase reflects the ideas that there is then less exogenous uncertainty and that the firm's stock market supplies a measure of the value of assets.

\section{Incentives in holding companies}

Managers of holding companies can be given stronger monetary incentives than their counterparts in the firms they control. First, portfolio diversification gets rid of some of the firm-specific noise. Second, the use of relative performance evaluation for holding companies eliminates some of the aggregate risk. Yet, the high level of noise in the environment limits the role of monetary incentives. Monitoring by, in particular, foreign institutions and (possibly independent) government representatives may therefore be quite important. Last, we would expect career concerns also to play some role in the noisy phase.

The reduction of noise in the mature phase allows even stronger monetary incentives and reduces the desirability of monitoring by the board of directors. It thus seems logical to phase out the former form of monitoring (attached to the absence of a market for shares of the holding companies). (Because the value of the holding companies can be continuously assessed by looking at the stock value of their shares in firms, monitoring by big shareholders or financial regulation seems less important than for firms or banks, respectively.)

\section{Regulatory incentive schemes}

Cost-of-service regulation has many unattractive features. Prominent among them is the firm's low incentive to reduce current cost or to introduce (nonmonetary) innovations. The firm benefits from the cost reduction for a short period until the next regulatory review, at which point the price is adjusted downward to reflect lower costs. Similarly the 
firm enjoys the benefits of an innovation only until the next regulatory review. This problem will be particularly serious in the EE environment: The many adjustments taking place in the economy (including input prices) require frequent price reviews for the regulated firm, which creates low incentives for cost reduction and innovation.

Cost-of-service regulation, the predominant mode of regulation in many countries until the $1980 \mathrm{~s}$, has been rightly decried, and more powerful incentive schemes (profit sharing provisions, price caps) have been introduced in some industries, in particular in the United States and the United Kingdom. Despite favoring incentive regulation in general, we would be reluctant to recommend its adoption during the noisy phase in EE. As discussed earlier, both the high level of uncertainty and the strong threat of regulatory capture call for low-powered incentive schemes such as cost-of-service regulation. Only when the uncertainty has been somewhat resolved and safeguards have been put in place to prevent capture can incentive regulation be introduced.

\section{Incentives and auctions}

The design of the inception stage must reflect several goals as discussed in Section 5; in particular, it must give the firm's owner during the noisy phase an incentive to invest; it must also give holding companies an incentive to collect information about the firms they will bid on, so as to create a relatively accurate measure of asset values at the inception stage. The firm will have some incentive to invest if its owner (the holding company) receives the proceeds of its auction and carefully monitors the firm. Managers of the firm will also be induced to invest by the nonstationarity of their incentive scheme: the low-powered incentives in the noisy phase reduce the cost of investment borne by managers, while the higher powered incentives in the mature phase allows them to benefit from these investments.

Earmarking shares on which the firm's owner is not allowed to bid is one simple way of creating liquidity in the stock market. The motivation was developed in Section 5. Its main purpose is not to create liquidity per se, but to give investors incentives to acquire information about the value of firms ${ }^{51}$ Forcing a firm to divest some of its shares eliminates to some extent the lemons problem associated with the voluntary sale or issue of shares. ${ }^{52}$

51. A concern is that the large number of auctions might induce the holding companies to rig bids. There are, however, some safeguards. First, the seller is not an outside seller such as the government, but one of the holding companies. Second, foreigners might be used as "potential entrants" to break collusion.

52. See Akerlof (1970) for the general issue, and Myers and Majluf (1984) for the application to corporate financing. See also the discussion in Section 5. 


\section{APPENDIX 3: COMPARISON WITH GROWTH COMPANIES}

Comparing the governance structure within the holding company to known governance structures helps clarify its nature. This appendix points at some analogies and differences with growth companies.

A firm controlled by a holding during the noisy phase and a growth company financed by venture capital both face very risky environments. They will not be traded on the stock market until a substantial fraction of the uncertainty about the technological and demand environment is resolved. In the meantime a major investor holds a substantial amount of equity in the firm: the holding in the first case, a venture capital partnership, a wealthy individual, or an investment institution in the second case. This investor carefully monitors and exerts control over the firm. ${ }^{53}$ The investor supplies substantial advice to inexperienced managers of the firm. He gives the money in several steps in order to be able to shut down the firm if necessary. Debt, which is very risky in this environment, plays a very minor role. In both cases, the rewards of the investor and the firm are delayed; and so is the public offering and the opening of the firm to new investors. ${ }^{54}$

Besides these many similarities, there is an essential difference between a subsidiary of a holding and a growth company: The incentives of the investor's and the firm's managers are low-powered in the case of a holding company. The fact that the managers of the holding company face low-powered incentives (some stocks, but mainly relative performance evaluation, monitoring, and career concerns) makes the holding resemble the investment division of a financial institution more than venture capitalists or wealthy individuals. More importantly, the firm's managers face very low-powered incentives (mainly monitoring and career concerns) while the founders of a growth company face highpowered incentives (at the beginning of the relationship they may hold half of the stock of the company). The explanation for this discrepancy is not due to differences in the marginal productivity of effort; in both cases, managerial input is quite crucial to the growth of the firm. Two

53. According to Brealey and Myers $(1988$, p. 326), venture capital investors do not necessarily demand a majority on the board of directors. A common compromise gives an equal number of seats to the founders and to outside investors. Coutarelli (1977, pp. 18,110 ) observes that the European venture capitalist does not seek a majority interest in the investee, but that they still exert substantial control (often, the venture capitalist becomes a majority shareholder by supplying further funds to the venture anyway).

54. Of course, some successful firms do not go public (examples include investmentbanking firms such as Goldman, Sachs \& Co., construction and engineering firms such as Bechtel, or stereo manufacturer Bose). These firms either are not capital intensive or else finance new investments through retained earnings and secured bank lines. 
other factors seem to generate the discrepancy. First, the founders of a growth firm usually can finance a nonnegligible fraction of initial expenses through savings and personal bank loans. In contrast, the managers of big privatized EE firms cannot purchase a substantial fraction of their firm's capital; nor can they use leverage in this very risky environment. This means that they will own a much smaller fraction of their firm than their counterparts in the growth firm. Second, it is hard to make the firm's managers accountable for the value of its assets during the noisy phase in EE. Because of the current idiosyncratic structure of production, firms will need to be broken into pieces and reorganized. In the absence of meaningful transfer prices for assets, it is difficult to identify the managers' individual contributions. In contrast, managers of a growth company are in charge of a well-defined and stable property.

\section{REFERENCES}

Akerlof, G. (1970). The market for lemons: Quality and the market mechanism. Quarterly Journal of Economics 84:488-500.

Blanchard, O., R. Dornbusch, P. Krugman, R. Layard, and L. Summers. (1990). Reform in Eastern Europe and the Soviet Union. Mimeo, UNU-WIDER, Helsinki.

Borensztein, E., and M. Kumar. (1990). Proposals for privatization in Eastern Europe. Mimeo, IMF.

Bradley, K., and A. Gelb. (1982). Motivation and control in the Mondragon experiment. British Journal of Industrial Relations 19:20-33.

-(1985). Employee buyouts of troubled companies. Harvard Business Review, 85 (September-October) 121-130.

Brealey, R., and S. Myers. (1988). Principles of Corporate Finance, 3rd ed. New York: McGraw-Hill.

Coutarelli, S. (1977). Venture Capital in Europe. New York: Praeger.

Dewatripont, M., and G. Roland. (1990). Economic reform and dynamic political constraints. Mimeo, Université Libre de Bruxelles.

Diamond, D. (1984). Financial intermediation and delegated monitoring. Review of Economic Studies 51:393-414.

Fischer, S. (1991). Privatization in East European transformation. Mimeo, MIT. Frydman, R., and A. Rapaczynski. (1990). Markets and institutions in large-scale privatizations. WP \#49, Center for Law and Economic Studies, Columbia University.

Gibbons, R., and K. Murphy. (1990). Relative performance evaluation for chief executive officers. Industrial and Labor Relations Review 43:30S-51S.

Grosfeld, I. (1990). Privatization of state enterprises in Eastern Europe: The search for a market environment. Document No. 90-17, DELTA, Paris.

Grossman, S., and O. Hart. (1980). Takeover bids, the free-rider problem and the theory of the corporation. Bell Journal of Economics 11:42-64.

Hart, O., and J. Tirole. (1990). Vertical integration and market foreclosure. Brookings Papers on Economic Activity: Microeconomics 205-286.

Herman, E. (1981). Corporate Control, Corporate Power. Cambridge: Cambridge University Press. 
Hinds, M. (1990). Issues in the introduction of market forces in Eastern European socialist economies. Mimeo, World Bank.

Holmström, B. (1982). Managerial incentives problems: A dynamic perspective. In Essays in Honor of Lars Wahlbeck. Helsinki: Swedish School of Economics. Holmström, B., and J. Tirole. (1989). The theory of the firm. In Handbook of Industrial Organization. R. Schmalensee and R. Willig (eds.). Amsterdam: North-Holland.

- (1990). Corporate control and the monitoring role of the stock market. Mimeo, Yale University and MIT.

Jensen, M. (1988). Takeovers: Their causes and consequences. Journal of Economic Perspectives 2:21-48.

Laffont, J.-J., and J. Tirole. (1986). Using cost observation to regulate firms. Journal of Political Economy 94:614-641.

- (1988). Repeated auctions of incentive contracts, investment and bidding parity, with an application to takeovers. Rand Journal of Economics 19:516-537.

- (1991). The politics of government decision making: A theory of regulatory capture. Quarterly Journal of Economics (in press).

Lee, T. (1982). Resource information policy and federal resource leasing. Bell Journal of Economics 13:561-568.

Lipton, D., and J. Sachs. (1990). Privatization in Eastern Europe: The case of Poland. Mimeo, Harvard University.

Mace, M. (1971). Directors: Myth and Reality. Harvard Business School.

Matthews, S. (1984). Information acquisition in discriminatory auctions. In Bayesian Models in Economic Theory. M. Boyer and R. Kihlstrom (eds.), pp. 181208. Amsterdam: North-Holland.

Milgrom, P. (1981). Rational expectations, information acquisition, and competitive bidding. Econometrica 49:921-944.

Myers, S., and N. Majluf. (1984). Corporate financing and investment decisions when firms have information that investors do not have. Journal of Financial Economics 13:187-221.

Narayanan, K. (1991). Bank influence and industrial concentration: A comparative study of post-war West Germany and Japan. Mimeo, MIT.

Newbery, D. (1990a). Tax reform, trade liberalization and industrial restructuring in Hungary. European Policy (in press).

- (1990b). Reform in Hungary: Sequencing and privatization. European Economic Review Papers and Proceedings 35:571-580.

Posner, R., and F. Easterbrook. (1981). Antitrust Cases, Economic Notes and Other Materials, 2nd ed. West Publishing Company. St. Paul, Minn.

Rausser, G., and L. Simon. (1991). The political economy of transition in Eastern Europe: Packaging enterprises for privatization. Mimeo, Univ. of California, Berkeley.

Riley, J. (1988). Ex post information in auctions. Review of Economic Studies 55:409-430.

Saldanha, F., and B. Milanovic. (1990). A proposal for a fast and efficient privatization of the state sector. The Privatization Review Fall:20-30.

Shleifer, A., and R. Vishny. (1986). Large shareholders and corporate control. Journal of Political Economy 94:461-488.

Siebert, H., and H. Schmieding. (1990). Restructuring industry in the GDR. Mimeo, Kiel Institute of World Economics. 
Stein, J. (1988). Takeover threats and managerial myopia. Journal of Political Economy 96:61-80.

. (1989). Efficient capital markets, inefficient firms: A model of myopic corporate behavior. Quarterly Journal of Economics 104:655-669.

Vickers, J., and G. Yarrow. (1988). Privatization: An Economic Analysis. Cambridge, MA: MIT Press.

- (1990a). Economic perspectives on privatization. Mimeo, Oxford University.

(1990b). The British electricity experiment. Mimeo, Oxford University.

Williamson, O. (1976). Franchise bidding for natural monopolies-In general and with respect to CATV. Bell Journal of Economics 7:73-104.

World Bank. (1988). Techniques of Privatization of State-Owned Enterprises, Volumes I, II, and III.

\title{
Comment
}

\author{
ALAN GELB \\ CECSE, World Bank
}

How does this paper fit into a macroeconomic conference? I asked, and was told that macro is whatever the organizers work on or consider important. Hopefully these categories have a large overlap! But the paper does indeed address a central area in the debate on the privatization of socialist countries-the trade-offs between equity, speed, and efficiency and the link to the last via corporate governance structures. Holding companies are sometimes proposed to focus the power of small owners and so to impose "people's capitalism." The paper goes further, to consider the incentive structures for enterprise managers and holding company managers, and relates these to the stage of reform.

Are holding companies a good idea at all? We could spend a long time discussing the paper in the broader context of privatization, but I prefer to recognize its high degree of focus and abstraction as its strength, and to comment within its own reference framework.

As a general point, transition paths do have longer-term effects on governance structures, through political-economic hysteresis effects. One example now evident is the difficulty of abolishing self-management, which emerged in the aftermath of the power vacuum caused by relaxing central control before resolving the ownership issue.

The paper has some excellent insights. I especially liked the characterization of the transition into a noisy (3-10 years?) and a quiet period, and the parallel with growth companies and the venture capital industry. This also suggests that in the phase of reorganization we may not be 
looking for conventional "managers," but for reorganizers or turnaround specialists.

Out of these insights the paper derives some conclusions that I think are right:

1. Stock markets work poorly in the noisy phase;

2. Gradualism in the introduction of such markets;

3. Political credibility as an obstacle to very high-powered schemes in noisy environments;

4. Low-powered incentives for regulated industries (here I agree only partly in that the firms must be allowed to pass on larger input price shocks); and

5. Competition-enhancing restructuring prior to privatization (but this should be evaluated in an open economy, not just national, context).

However, I would not have derived some other conclusions of the paper. First, we must be clear on the roles of the two types of managers. There are two cases:

1. The holding has a wide and diverse group of firms with little obvious synergy (for diversification of its portfolio). The presumption then is that the firm's manager (the "insider") has superior information on its activities and potential. The holding should not cross-subsidize via transfer pricing, etc. The governance problem is the conventional one.

2. Some reorganization may require a "sector" approach that will be inhibited if the firms in that sector are dispersed across different holdings. So we might have a "sector holding" (say steel) as a reorganizational device. As the holding intervenes in its firms with a broader view, managers of the firm cannot be held finally accountable as in case (1). They could conceivably receive shares in the sector but not in that firm.

Let us put case (2) on one side and focus on case (1). The paper argues for low-power incentives in the noisy phase, because of the impact of noise on a structure of rewards based on stock market valuations. True, a noisy market will not reflect management quality and effort efficiently. But high noise will weaken all forms of management evaluation and oversight because we can never know the characteristics of all states of the world well enough to separate out the management inputs. Consider career concerns. There will be plenty of real or spurious exogenous 
shocks on which to blame failure-how do we tell the difference? Monitoring? If this were really possible, why consider incentives at all? In particular, this paper does not note the key trade-offs between monitoring capability and portfolio diversification.

I would formulate an alternative proposition: high noise means large management discretion. It is then even more vital to seek out and offer high-powered incentives. But these must be designed to minimally distort decision making - again because of the weakness of monitoring. This argues against bonuses based on short-term performance, and in favor of deferred, but possibly substantial, compensation, say, through stock options to be exercised at the end of the noisy phase.

In this connection, the paper overemphasizes the need for liquid stock markets to value assets. Few countries have such markets, and they cover only part of corporate assets at best. But firms are bought and sold all the time so assets are being valued. Extreme noise, rather than the absence of a liquid market, is the main current problem in valuing assets in East Europe. Therefore, it is not out of the question to consider high-power incentives that are deferred for some 3-10 years. If the managers are foreign, these can be structured so as to reduce the impact on long-term ownership patterns-for example, by offering shares of the company that must be sold out to domestic bidders over a number of subsequent years. Such arrangements have been used in some developing countries to encourage direct investment and at the same time to reduce fears of loss of national sovereignty. Another example is the French "core group" approach, where a stable core is locked in to provide continuous management in the transition and some shares are later offered to small investors at a discount, reflecting the better control and information position of the management group.

The venture capital industry is a good analogy. It works on the basis of pervasive high-powered and deferred incentives, to managers and those monitoring. Neither of the reasons given as to why the East European case is different is persuasive: (1) Whether or not they have invested is irrelevant in considering incentives for the firm and fund managers; you want them to behave as if they had; and (2) the difficulty of other forms of monitoring in the noisy phase is downplayed. Note too that highpowered incentives may help to self-select out candidates from the pool of potential managers, if individuals appreciate their own potential managerial skills better than those selecting them.

The suggestion that foreign funds be used for loans rather than equity investments runs up against the problem of nonbankable risk (rising interest rates leading to deteriorating portfolios because of adverse selection of borrowers and moral hazard). Lending to the holdings instead 
confronts their monitoring problem, referred to above. This is not an easy out.

Regulatory capture is a problem. But it is possibly serious whether or not incentives are high powered, because the rents generated by capture can be appropriated by employees as well.

Finally-noise implies rents. I see no way to sustain ex post equality and at the same time to establish incentive structures needed for the task ahead. Hopefully, we shall see some interesting experiments in East Europe soon, to enable us to better assess the various trade-offs and options that are the subject of this paper.

\section{Comment}

\section{ROBERT W. VISHNY}

Graduate School of Business, University of Chicago and NBER

I would like to preface my remarks by thanking Robert Hamada, Ed Lazear, and Michael Mussa from the Graduate School of Business, University of Chicago for helpful discussions on privatization surrounding our recent visit to Czechoslovakia. I learned a lot about privatization on that trip.

While it is hard to come up with something completely new on a topic as widely discussed as privatization in Eastern Europe, Jean Tirole has managed to make a nice contribution to that growing literature. His is mostly a synthesis paper with careful justifications and arguments offered for and against many popular policy prescriptions. But there is also a slightly different emphasis here: he discusses not only how to structure the ownership and incentives in existing "enterprises," but also how to restructure the enterprises themselves before privatization. I think that this is a very important problem that is too often overlooked in papers on privatization.

Tirole is principally concerned with the problem of promoting competitive behavior since many state enterprises are monopoly providers of goods and services. While new firms would presumably be allowed to form and compete with privatized former state enterprises, one could provide even more effective competition in many cases by breaking up existing state monopolies and dividing up their assets and employees.

In general, governments such as Czechoslovakia's are grappling with the problem of how to evaluate competing proposals for privatization and deciding whether a given enterprise's assets will be completely or partially sold to foreigners, become part of a joint venture, split up into 
separate entities based on geography or product lines, or else privatized as is. These decisions seem to be taking place on a case by case basis and could be helped considerably by a set of consistent guidelines and a requirement that the state conduct a competition among various proposals for privatizing a particular enterprise rather than just allowing each enterprise's current top management to draw up the only plan.

I endorse Tirole's emphasis on restructuring existing enterprises before privatization. I would even extend the point to say that the governments should also consider breaking up certain large conglomerates that operate in many disparate businesses. First, in many cases, a potential business partner will be interested in only a part of the enterprise. Second, I think the potential for cross-subsidization of unprofitable businesses even after privatization is great, which makes a division of a large conglomerate less subject to the discipline of a hard budget constraint. When incumbent management stays on to run the enterprise the risk of this cross-subsidization and commitment to marginal businesses will be even greater. Of course, on the other side of the coin we have the value of an internal capital market provided by a conglomerate structure at a time when external capital markets may not be operating very well. Third, the U.S. experience appears to show that conglomerates are not the most efficient way to organize. While the EE private sector may come to realize this and force changes in organizations over time, it may make sense to bias the starting conditions for those economies in the right direction. Finally, even when highly diversified enterprises are privatized as is, it will be important to set in place an accounting system that treats each business as a separate profit center rather than obscure the cross-subsidization that is going on via transfer pricing.

My main reservation about this paper is that it overemphasizes the importance of uncertainty over the pricing of assets. Distrust of market prices for individual assets is one of the reasons for the holding company structure as well as the prescription for low powered incentives for managers of firms. I agree with Tirole that the pricing of these assets will be subject to great uncertainty and that there may be big winners and losers ex post if assets are simply sold off. But one must be aware that trying to ensure ex post fairness to all parties may come at a high cost in terms of economic growth and efficiency.

For example, I think it is essential to encourage the inflow of capital and expertise from abroad as soon as possible if current consumption standards are to be maintained and essential infrastructure is built. This may not be facilitated by the holding company structure. It may make more sense to sell off certain assets to foreigners or domestics from the beginning so that they can start investing immediately. It would proba- 
bly be a mistake to wait 5 or 10 years until market values are better established to start selling assets. It seems unlikely that people will invest when property rights are not well established. I know that foreign investors in joint ventures often demand assurances about the governance structure and the board of directors that may not be feasible under the envisioned holding company structure.

I am also concerned that the envisioned holding company structure moves too far away from the concept of creating concentrated ownership interests in individual enterprises and minimizing the role of politics and government in business decision making. I understand most of these proposals as specifying a small number of holding companies that would own and run the economy, say 10 or 20 . There seem to be several problems with this. First, if we think about 1500 large enterprises after restructuring and privatization, how are 10-20 holding company boards going to have the time and incentive to monitor 75-150 firms each? The benefit of having individual firms each with its own set of large shareholders to monitor the management would be substantially diminished. Second, with 10 or 20 holding companies, each holding substantial portions or large numbers of firms, I keep thinking that these holding companies look a lot like government ministries and would probably be subject to the same political pressures as a government running the economy. For example, these holding companies would probably be vulnerable to coordinated strikes for higher wages by workers in all of their enterprises. In addition, members of the board of directors of one of those holding companies would have tremendous power and there would seem to be huge scope for graft. The answer to this latter problem is public accountability through the voting mechanism, but this seems likely to politicize the holding companies as I argued before.

The answer to all these problems would seem to be creating a larger number of separate firms, each with its own concentrated ownership structure in order to provide for the proper incentives. The holding company structure may be more appropriate for the very largest firms (that is, a fraction of the 500-1500 largest firms), but in order to provide incentives to all but the very largest firms, I would think that concentrated direct shareholdings in the firm would be desirable. These would include ownership by management as well as by domestics or foreigners (individuals or institutions) who buy equity stakes in the firms. Clearly, when it comes to small scale privatization, most people have no objections to simply selling them off, and everyone agrees that this is the best way to ensure that someone takes an active interest in improving the performance of those assets. I think that the same principles should be 
applied to the large scale privatization, especially at the smaller end of the 1500 largest enterprises.

Tirole's objection to providing managers high powered incentives in the form of equity stakes is that there is too much uncertainty about the ultimate value of the firm's equity during the "noisy" period. I agree that values will be extremely uncertain for awhile, but I do not think that this should stand in the way of providing managers with incentives or allowing individuals or institutions to buy large pieces of firms and establish property rights. If the risk to management is large due to fluctuating values, then be a little more generous and give the management a reasonable fixed salary as well as good upside potential via stock or stock options. If there is a question about managers using their inside information to trade, then simply give them restricted stock (which is common in the United States) that cannot be sold for 5 or 7 years. Out of the money options could be used to ensure that managers are not too risk averse because of their contingent compensation.

As far as outside investors are concerned, there is no doubt that allowing assets to trade before values are well-established will create ex post winners and losers, but I think this may be necessary to establish property rights and encourage investment as everyone agrees is the right policy for the small-scale privatization. I am also a little more optimistic about the ability of individuals and institutions to accumulate concentrated stakes in individual firms. Apart from foreigners who must be encouraged because of tremendous capital needs, domestics should also be able to accumulate concentrated stakes. First, in some countries generous restitution programs will create large pockets of wealth. Second, individuals should be able to pool their "voucher points" via financial institutions that will invest on their behalf and take large stakes in individual enterprises. The government could even encourage these institutions to hold large stakes in individual enterprises, by imposing lower taxes on dividends from such holdings.

Finally, while the problem of providing incentives to managers and monitoring by outside shareholders is important, it may be even more important to ensure a rapid inflow of expertise and capital into Eastern Europe. Moreover, capital and expertise at the World Bank, IMF, and EBRD are limited, so we must look to investment by foreigners in individual enterprises as an important source of capital and expertise. This can take place via joint ventures or outright sale of existing state assets to foreigners. While joint ventures may be more palatable politically, it should be recognized that they still require some kind of valuation of existing assets that determines the capital contribution the outsider must 
make in exchange for his share of the profits/revenues, etc. Outside investment cannot be encouraged without some kind of claim to cash flows and decision rights. This will entail effectively selling assets when their value is highly uncertain and also agreeing to governance structures that may be incompatible with the envisioned holding company structure.

\section{Discussion}

Sweder van Wijnbergen suggested that dissolving the holding companies may prove to be difficult. For example, in 1945 Italy created ENI, which by law would be dissolved in 5 years. Instead, it is now the largest industrial conglomerate. He also offered that attracting foreign investment will be costly. High temporary uncertainty means the option value of investment is high, leading to delay.

Robert Barro objected to the notion that there is necessarily an equityefficiency trade-off. Formerly, in Eastern Europe the distribution of political perks, which should be measured as part of personal wealth, was very uneven. He also wondered why the role of stock markets should be minimized in the beginning. Sorting through noise is what stock markets are designed to do. Moreover, property rights will be distributed rather arbitrarily, and therefore it seems important to allow people to trade their claims. Tirole answered that the stock market will not measure manager performance well in the noisy phase, and incentive schemes will not work well. One will have to provide monitoring, and traditionally stock markets have played a minor role in monitoring.

Robert Gordon asked whether an important element of foreign investment was expertise. Was General Electric's experience in Hungary typical? Tirole noted expertise can be rented; it need not come only in the form of ownership. Julio Rotemberg pointed out that foreign involvement may cause problems in that foreign investors may just acquire assets cheaply. In addition, comparing Hong Kong, Taiwan, and Singapore, Singapore used more foreign firms, but Hong Kong and Taiwan seem to have fostered higher total productivity growth. Work by Michael Cusumano shows that Toyota used much less foreign expertise than Nissan but had more technological progress. Paul Romer suggested that the discussion of incentives and inefficiencies can be thought of as lying in a wrong place in the production possibility frontier. The discussion on foreign expertise can be thought of as shifts in the frontier. This latter model should be given as much emphasis. 
Paul Marer questioned the assumption that ownership claims will be distributed more or less free to the population. He stated that East European governments and central banks have large liabilities, nonperforming debts of the banking system, large foreign debts, and environmental legacies. The governments are counting on the income generated by the sale of properties and enterprises to finance these liabilities. Robert Gordon indicated that restitution to former owners of assets is another distributional issue.

Alan Gelb noted that an important element lost in the discussion of traded goods is the disastrous state of services. Telecommunications, information processing, accounting, and financial services are all important elements of a competitive manufacturing base. These industries will need to improve. 
